\title{
High COVID-19 Attack Rate Among Attendees at Events at a Church - Arkansas, March 2020
}

\author{
Allison James, DVM, PhD ${ }^{1,2}$; Lesli Eagle ${ }^{1}$; Cassandra Phillips ${ }^{1}$; D. Stephen Hedges, $\mathrm{MPH}^{1}$; Cathie Bodenhamer ${ }^{1}$; Robin Brown, MPAS, MPH ${ }^{1}$; \\ J. Gary Wheeler, $\mathrm{MD}^{1}$; Hannah Kirking, $\mathrm{MD}^{3}$
}

\begin{abstract}
On May 19, 2020, this report was posted as an MMWR Early Release on the MMWR website (https://www.cdc.gov/mmwr).
\end{abstract}

On March 16, 2020, the day that national social distancing guidelines were released (1), the Arkansas Department of Health (ADH) was notified of two cases of coronavirus disease 2019 (COVID-19) from a rural county of approximately 25,000 persons; these cases were the first identified in this county. The two cases occurred in a husband and wife; the husband is the pastor at a local church (church A). The couple (the index cases) attended church-related events during March 6-8, and developed nonspecific respiratory symptoms and fever on March 10 (wife) and 11 (husband). Before his symptoms had developed, the husband attended a Bible study group on March 11 . Including the index cases, 35 confirmed COVID-19 cases occurred among 92 (38\%) persons who attended events held at church A during March 6-11; three patients died. The agespecific attack rates among persons aged $\leq 18$ years, 19-64 years, and $\geq 65$ years were $6.3 \%, 59.4 \%$, and $50.0 \%$, respectively. During contact tracing, at least 26 additional persons with confirmed COVID-19 cases were identified among community members who reported contact with church $A$ attendees and likely were infected by them; one of the additional persons was hospitalized and subsequently died. This outbreak highlights the potential for widespread transmission of SARS-CoV-2, the virus that causes COVID-19, both at group gatherings during church events and within the broader community. These findings underscore the opportunity for faith-based organizations to prevent COVID-19 by following local authorities' guidance and the U.S. Government's Guidelines: Opening Up America Again (2) regarding modification of activities to prevent virus transmission during the COVID-19 pandemic.

On March 10 and 11, the wife of the church pastor, aged 56 years, and the pastor, aged 57 years, developed fever and cough. On March 12, the pastor, after becoming aware of similar nonspecific respiratory symptoms among members of their congregation, closed church A indefinitely. Because of fever, cough, and increasing shortness of breath, the couple sought testing for SARS-CoV-2 on March 13; both were notified of positive results by reverse transcription-polymerase chain reaction testing on March 16. The same day, ADH staff members began an investigation to identify how the couple had been exposed and to trace persons with whom they had been in contact. Based on their activities and onset dates, they likely were infected at church A events during March 6-8, and the husband might have then exposed others while presymptomatic during a Bible study event held on March 11.

During March and April 2020, all persons in Arkansas who received testing for SARS-CoV-2 at any laboratory were entered into a database (Research Electronic Data Capture [REDCap]; version 8.8.0; Vanderbilt University) managed by $\mathrm{ADH}$. Using a standardized questionnaire, $\mathrm{ADH}$ staff members interviewed persons who had positive test results to ascertain symptoms, onset date, and potential exposure information, including epidemiologic linkages to other COVID-19 patients; this information was stored in the database. Close contacts of patients with laboratory-confirmed cases of COVID-19 were interviewed and enrolled in active symptom monitoring; those who developed symptoms were tested and their information was also entered into the database. Church $\mathrm{A}$-associated cases were defined as those in 1) persons who had laboratory results positive for SARS-CoV-2 who identified contact with church A attendees as a source of exposure and 2) actively monitored contacts of church attendees who had a test result positive for SARS-CoV-2 after becoming symptomatic.

The public health investigation focused on the transmission of SARS-CoV-2 among persons who attended church A events during March 6-11. To facilitate the investigation, the pastor and his wife generated a list of 94 church members and guests who had registered for, or who, based on the couple's recollection, might have attended these events.

During March 6-8, church A hosted a 3-day children's event which consisted of two separate 1.5-hour indoor sessions (one on March 6 and one on March 7) and two, 1-hour indoor sessions during normal church services on March 8 . This event was led by two guests from another state. During each session, children participated in competitions to collect offerings by hand from adults, resulting in brief close contact among nearly all children and attending adults. On March 7, food prepared by church members was served buffet-style. A separate Bible study event was held March 11; the pastor reported most attendees sat apart from one another in a large room at this event. Most children and some adults participated in singing during the children's event; no singing occurred during the March 11 Bible study. Among all 94 persons who might have attended any of the events, $19(20 \%)$ attended both the children's event and Bible study. 


\section{Summary}

What is already known about this topic?

Large gatherings pose a risk for SARS-CoV-2 transmission.

What is added by this report?

Among 92 attendees at a rural Arkansas church during March 6-11, 35 (38\%) developed laboratory-confirmed COVID-19, and three persons died. Highest attack rates were in persons aged $19-64$ years (59\%) and $\geq 65$ years $(50 \%)$. An additional 26 cases linked to the church occurred in the community, including one death.

What are the implications for public health practice?

Faith-based organizations should work with local health officials to determine how to implement the U.S. Government guidelines for modifying activities during the COVID-19 pandemic to prevent transmission of the virus to their members and their communities.

The husband and wife were the first to be recognized by $\mathrm{ADH}$ among the 35 patients with laboratory-confirmed COVID-19 associated with church A attendance identified through April 22; their illnesses represent the index cases. During the investigation, two persons who were symptomatic (not the husband and wife) during March 6-8 were identified; these are considered the primary cases because they likely initiated the chain of transmission among church attendees. Additional cases included those in persons who attended any church A events during March 6-11, but whose symptom onset occurred on or after March 8, which was 2 days after the earliest possible church A exposure. One asymptomatic attendee who sought testing after household members became ill was included among these additional cases.

Consistent with CDC recommendations for laboratory testing at that time (3), clinical criteria for testing included cough, fever, or shortness of breath; asymptomatic persons were not routinely tested. To account for this limitation when calculating attack rates, upper and lower boundaries for the attack rates were estimated by dividing the total number of persons with laboratory-confirmed COVID-19 by the number of persons tested for SARS-CoV-2 and by the number of persons who attended church A during March 6-11, respectively. All analyses were performed using R statistical software (version 4.0.0; The R Foundation). Risk ratios were calculated to compare attack rates by age, sex, and attendance dates. Fisher's exact test was used to calculate two-sided $\mathrm{p}$-values; $\mathrm{p}$-values $<0.05$ were considered statistically significant.

Overall, 94 persons attended church A events during March 6-11 and might have been exposed to the index patients or to another infectious patient at the same event; among these persons, 92 were successfully contacted and are included in the analysis. Similar proportions of church A attendees were aged $\leq 18$ years $(35 \%), 19-64$ years $(35 \%)$, and $\geq 65$ years $(30 \%)$ (Table 1). However, a higher proportion of adults aged $19-64$ years and $\geq 65$ years were tested $(72 \%$ and $50 \%$, respectively), and received positive test results (59\% and 50\%), than did younger persons. Forty-five persons were tested for SARS-CoV-2, among whom $35(77.8 \%)$ received positive test results (Table 2).

During the investigation, two church A participants who attended the March 6-8 children's event were found to have had onset of symptoms on March 6 and 7; these represent the primary cases and likely were the source of infection of other church A attendees (Figure). The two out-of-state guests developed respiratory symptoms during March 9-10 and later received diagnoses of laboratory-confirmed COVID-19, suggesting that exposure to the primary cases resulted in their infections. The two primary cases were not linked except through the church; the persons lived locally and reported no travel and had no known contact with a traveler or anyone with confirmed COVID-19. Patient interviews revealed no additional common exposures among church attendees.

The estimated attack rate ranged from 38\% (35 cases among all 92 church A event attendees) to 78\% (35 cases among 45 church A event attendees who were tested for SARS-CoV-2). When stratified by age, attack rates were significantly lower among persons aged $\leq 18$ years $(6.3 \%-25.0 \%)$ than among adults aged $19-64$ years $(59.4 \%-82.6 \%)(\mathrm{p}<0.01)$. The risk ratios for persons aged $\leq 18$ years compared with those for persons aged 19-64 years were 0.1-0.3. No severe illnesses occurred in children. Among the 35 persons with laboratoryconfirmed COVID-19, seven (20\%) were hospitalized; three (9\%) patients died.

At least 26 additional confirmed COVID-19 cases were identified among community members who, during contact tracing, reported contact with one or more of the 35 church A members with COVID-19 as an exposure. These persons likely were infected by church A attendees. Among these 26 persons, one was hospitalized and subsequently died. Thus, as of April 22, 61 confirmed cases (including eight [13\%] hospitalizations and four [7\%] deaths) had been identified in persons directly and indirectly associated with church $\mathrm{A}$ events.

\section{Discussion}

This investigation identified 35 confirmed COVID-19 cases among 92 attendees at church A events during March 6-11; estimated attack rates ranged from $38 \%$ to $78 \%$. Despite canceling in-person church activities and closing the church as soon as it was recognized that several members of the congregation had become ill, widespread transmission within church A and within the surrounding community occurred. The primary patients had no known COVID-19 exposures in 
Morbidity and Mortality Weekly Report

TABLE 1. Demographic characteristics, church A event attendance, and SARS-CoV-2 testing status of persons who attended church A events where persons with confirmed COVID-19 ( $\mathrm{N}=92)$ also attended - Arkansas, March 2020

\begin{tabular}{|c|c|c|c|c|c|}
\hline Characteristic & $\begin{array}{l}\text { All attendees } \\
\text { No. }(\%)^{*}\end{array}$ & $\begin{array}{l}\text { No. }(\%) \\
\text { tested }^{\dagger}\end{array}$ & p-value ${ }^{\S}$ & $\begin{array}{c}\text { No. (\%) } \\
\text { who tested positive }^{\dagger}\end{array}$ & p-value \\
\hline Total & $92(100)$ & $45(49)$ & - & $35(38)$ & - \\
\hline $\begin{array}{l}\text { Age group (yrs) } \\
\leq 18 \\
18-64 \\
\geq 65\end{array}$ & $\begin{array}{l}32(35) \\
32(35) \\
28(30)\end{array}$ & $\begin{array}{r}8(25) \\
23(72) \\
14(50)\end{array}$ & 0.001 & $\begin{array}{r}2(6) \\
19(59) \\
14(50)\end{array}$ & 0.004 \\
\hline $\begin{array}{l}\text { Sex } \\
\text { Male } \\
\text { Female }\end{array}$ & $\begin{array}{l}44(48) \\
48(52)\end{array}$ & $\begin{array}{l}22(50) \\
23(48)\end{array}$ & 1.0 & $\begin{array}{l}17(39) \\
18(38)\end{array}$ & 1.0 \\
\hline $\begin{array}{l}\text { Church A event attendance } \\
\text { Weekend only (Mar 6-8) } \\
\text { Bible study only (Mar 11) } \\
\text { Both weekend and Bible study }\end{array}$ & $\begin{array}{r}64(70) \\
9(10) \\
19(21)\end{array}$ & $\begin{array}{r}33(52) \\
2(22) \\
10(53)\end{array}$ & 0.28 & $\begin{array}{r}28(44) \\
1(11) \\
6(32)\end{array}$ & 0.16 \\
\hline
\end{tabular}

Abbreviation: COVID-19 = coronavirus disease 2019.

* Includes all persons who were confirmed to have attended church A events during March 6-11; percentages are column percentages.

$\dagger$ Percentage of attendees (row percentages).

$\S$ Calculated with Fisher's exact test.

TABLE 2. Estimated attack rates of COVID-19 among attendees at church A events - Arkansas, March 6-11, 2020

\begin{tabular}{|c|c|c|c|c|c|c|}
\hline \multirow[b]{2}{*}{ Characteristic } & \multicolumn{3}{|c|}{$\begin{array}{l}\text { All Mar 6-11 church } A \text { attendees } \\
\text { (lower bound) }\end{array}$} & \multicolumn{3}{|c|}{$\begin{array}{l}\text { All tested Mar 6-11 church } A \text { attendees } \\
\text { (upper bound) }\end{array}$} \\
\hline & No. of cases/no. exposed (\%) & Risk ratio $(95 \% \mathrm{Cl})$ & p-value & No. of cases/no. tested (\%) & Risk ratio $(95 \% \mathrm{Cl})$ & $p$-value \\
\hline Overall & $35 / 92(38.0)$ & - & - & $35 / 45(77.8)$ & - & - \\
\hline $\begin{array}{l}\text { Age group (yrs) } \\
\leq 18 \\
19-64 \\
\geq 65\end{array}$ & $\begin{array}{r}2 / 32(6.3) \\
19 / 32(59.4) \\
14 / 28(50.0)\end{array}$ & $\begin{array}{r}0.1(0.03-0.4) \\
\text { Referent } \\
0.8(0.5-1.3)\end{array}$ & $\begin{array}{c}<0.001 \\
- \\
0.47\end{array}$ & $\begin{array}{r}2 / 8(25.0) \\
19 / 23(82.6) \\
14 / 14(100.0)\end{array}$ & $\begin{array}{r}0.3(0.1-1.0) \\
\text { Referent } \\
1.2(1.0-1.5)\end{array}$ & $\begin{array}{l}0.003 \\
- \\
0.10\end{array}$ \\
\hline $\begin{array}{l}\text { Sex } \\
\text { Male } \\
\text { Female }\end{array}$ & $\begin{array}{l}17 / 44(38.6) \\
18 / 48(37.5)\end{array}$ & $\begin{array}{r}1.0(0.6-1.7) \\
\text { Referent }\end{array}$ & $\begin{array}{c}0.91 \\
-\end{array}$ & $\begin{array}{l}17 / 22(77.3) \\
18 / 23(78.3)\end{array}$ & $\begin{array}{r}1.0(0.7-1.3) \\
\text { Referent }\end{array}$ & $\begin{array}{c}0.94 \\
-\end{array}$ \\
\hline $\begin{array}{l}\text { Church A event attendance } \\
\text { Weekend only (Mar 6-8) } \\
\text { Bible study only (Mar 11) } \\
\text { Both weekend and Bible study }\end{array}$ & $\begin{array}{r}28 / 64(43.8) \\
1 / 9(11.1) \\
6 / 19(31.6)\end{array}$ & $\begin{array}{r}1.4(0.7-2.8) \\
0.4(0.05-2.5) \\
\text { Referent }\end{array}$ & $\begin{array}{l}0.3 \\
0.25 \\
-\end{array}$ & $\begin{array}{r}28 / 33(84.8) \\
1 / 2(50.0) \\
6 / 10(60.0)\end{array}$ & $\begin{array}{r}1.4(0.8-2.4) \\
1.7(0.4-6.8) \\
\text { Referent }\end{array}$ & $\begin{array}{c}0.09 \\
0.21 \\
-\end{array}$ \\
\hline
\end{tabular}

Abbreviations: $\mathrm{Cl}$ = confidence interval; COVID-19 = coronavirus disease 2019.

the 14 days preceding their symptom onset dates, suggesting that local transmission was occurring before case detection.

Children represented $35 \%$ of all church A attendees but accounted for only $18 \%$ of persons who received testing and $6 \%$ of confirmed cases. These findings are consistent with those from other reports suggesting that many children with COVID-19 experience more asymptomatic infections or milder symptoms and have lower hospitalization rates than do adults $(4,5)$. The role of asymptomatic or mildly symptomatic children in SARS-CoV-2 transmission remains unknown and represents a critical knowledge gap as officials consider reopening public places.

The risk for symptomatic infection among adults aged $\geq 65$ years was not higher than that among adults aged 19-64 years. However, six of the seven hospitalized persons and all three deaths occurred in persons aged $\geq 65$ years, consistent with other U.S. data indicating a higher risk for
COVID-19-associated hospitalization and death among persons aged $\geq 65$ years $(6)$.

The findings in this report are subject to at least four limitations. First, some infected persons might have been missed because they did not seek testing, were ineligible for testing based on criteria at the time, or were unable to access testing. Second, although no previous cases had been reported from this county, undetected low-level community transmission was likely, and some patients in this cluster might have had exposures outside the church. Third, risk of exposure likely varied among attendees but could not be characterized because data regarding individual behaviors (e.g., shaking hands or hugging) were not collected. Finally, the number of cases beyond the cohort of church attendees likely is undercounted because tracking out-of-state transmission was not possible, and patients might not have identified church members as their source of exposure. 
FIGURE. Date of symptom onset* among persons with laboratory-confirmed cases of COVID-19 (N = 35) who attended March 6-11 church A events - Arkansas, March 6-23, 2020

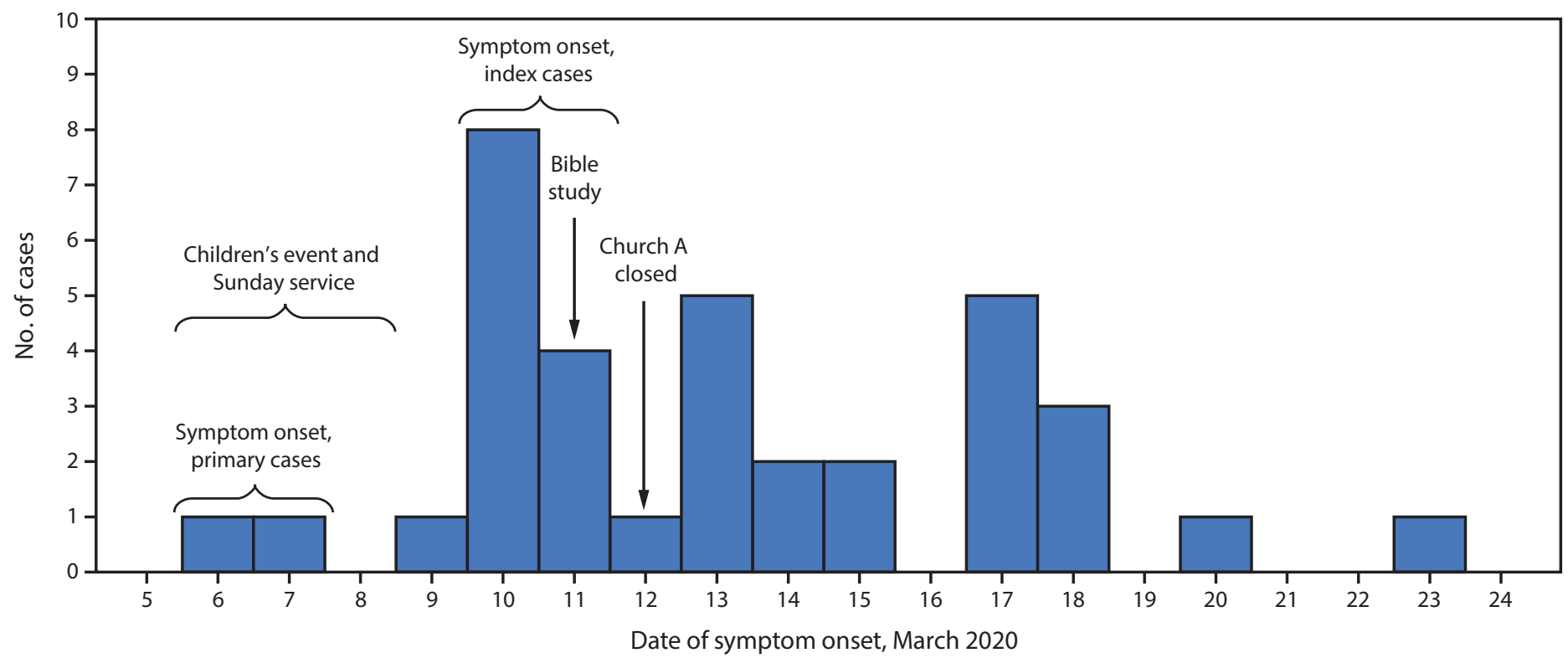

Abbreviation: COVID-19 = coronavirus disease 2019.

* One asymptomatic person who had a positive test result is included on the date of specimen collection (March 18).

High transmission rates of SARS-CoV-2 have been reported from hospitals (7), long-term care facilities (8), family gatherings (9), a choir practice (10), and, in this report, church events. Faith-based organizations that are operating or planning to resume in-person operations, including regular services, funerals, or other events, should be aware of the potential for high rates of transmission of SARS-CoV-2. These organizations should work with local health officials to determine how to implement the U.S. Government's guidelines for modifying activities during the COVID-19 pandemic to prevent transmission of the virus to their members and their communities (2).

\section{Acknowledgments}

Members of the congregation of church A, including the pastor and his wife; Arkansas Department of Health; Suzanne Beavers, CDC; Laura Rothfeldt, Arkansas Department of Health; state and local health departments where out-of-state visitors resided.

Corresponding author: Allison E. James, hwj7@cdc.gov, 501-614-5278.

${ }^{1}$ Arkansas Department of Health; ${ }^{2}$ Epidemic Intelligence Service, CDC; ${ }^{3}$ COVID-19 Response Team, CDC.

All authors have completed and submitted the International Committee of Medical Journal Editors form for disclosure of potential conflicts of interest. No potential conflicts of interest were disclosed.

\section{References}

1. Office of the President of the United States. Coronavirus guidelines for America. Washington, DC: Office of the President of the United States; 2020. https://www.whitehouse.gov/briefings-statements/coronavirusguidelines-america/
2. Office of the President of the United States. Guidelines: opening up America again. Washington, DC: Office of the President of the United States; 2020. https://www.whitehouse.gov/openingamerica/

3. CDC. Health Alert Network: update and interim guidance on outbreak of coronavirus disease 2019 (COVID-19). Atlanta, GA: US Department of Health and Human Services, CDC; 2020. https://emergency.cdc.gov/ han/2020/HAN00428.asp

4. Bialek S, Gierke R, Hughes M, McNamara LA, Pilishvili T, Skoff T; CDC COVID-19 Response Team. Coronavirus disease 2019 in childrenUnited States, February 12-April 2, 2020. MMWR Morb Mortal Wkly Rep 2020;69:422-6. https://doi.org/10.15585/mmwr.mm6914e4

5. Dong Y, Mo X, Hu Y, et al. Epidemiology of COVID-19 among children in China. Pediatrics 2020. Epub March 16, 2020. https://doi. org/10.1542/peds.2020-0702

6. Bialek S, Boundy E, Bowen V, et al.; CDC COVID-19 Response Team. Severe outcomes among patients with coronavirus disease 2019 (COVID-19)—United States, February 12-March 16, 2020. MMWR Morb Mortal Wkly Rep 2020;69:343-6. https://doi.org/10.15585/ mmwr.mm6912e2

7. Heinzerling A, Stuckey MJ, Scheuer T, et al. Transmission of COVID-19 to health care personnel during exposures to a hospitalized patientSolano County, California, February 2020. MMWR Morb Mortal Wkly Rep 2020;69:472-6. https://doi.org/10.15585/mmwr.mm6915e5

8. McMichael TM, Currie DW, Clark S, et al. Epidemiology of Covid-19 in a long-term care facility in King County, Washington. N Engl J Med 2020. Epub March 27, 2020. https://doi.org/10.1056/NEJMoa2005412

9. Ghinai I, Woods S, Ritger KA, et al. Community transmission of SARS$\mathrm{CoV}-2$ at two family gatherings - Chicago, Illinois, February-March 2020. MMWR Morb Mortal Wkly Rep 2020;69:446-50. https://doi. org/10.15585/mmwr.mm6915e1

10. Hamner L, Dubbel P, Capron I, et al. High SARS-CoV-2 attack rate following exposure at a choir practice-Skagit County, Washington, March 2020. MMWR Morb Mortal Wkly Rep 2020;69:606-10. https:// doi.org/10.15585/mmwr.mm6919e6 